Review

\title{
A New Gal in Town: A Systematic Review of the Role of Galanin and Its Receptors in Experimental Pain
}

\author{
Diana Fonseca-Rodrigues ${ }^{1,2} \mathbb{D}$, Armando Almeida ${ }^{1,2}$ and Filipa Pinto-Ribeiro ${ }^{1,2, * \mathbb{D}}$ \\ 1 Life and Health Sciences Research Institute (ICVS), Campus of Gualtar, School of Medicine, University of \\ Minho, 4710-057 Braga, Portugal; id10192@alunos.uminho.pt (D.F.-R.); aalmeida@med.uminho.pt (A.A.) \\ 2 ICVS/3B's—PT Government Associate Laboratory, 4805-017 Guimarães, Portugal \\ * Correspondence: filiparibeiro@med.uminho.pt; Tel.: +351-253604852
}

check for updates

Citation: Fonseca-Rodrigues, D.; Almeida, A.; Pinto-Ribeiro, F. A New Gal in Town: A Systematic Review of the Role of Galanin and Its Receptors in Experimental Pain. Cells 2022, 11, 839. https://doi.org/10.3390/ cells11050839

Academic Editor: Ellen Niederberger

Received: 3 February 2022

Accepted: 28 February 2022

Published: 1 March 2022

Publisher's Note: MDPI stays neutral with regard to jurisdictional claims in published maps and institutional affiliations.

Copyright: (C) 2022 by the authors. Licensee MDPI, Basel, Switzerland. This article is an open access article distributed under the terms and conditions of the Creative Commons Attribution (CC BY) license (https:// creativecommons.org/licenses/by/ $4.0 /)$.

\begin{abstract}
Galanin is a neuropeptide expressed in a small percentage of sensory neurons of the dorsal root ganglia and the superficial lamina of the dorsal horn of the spinal cord. In this work, we systematically reviewed the literature regarding the role of galanin and its receptors in nociception at the spinal and supraspinal levels, as well as in chronic pain conditions. The literature search was performed in PubMed, Web of Science, Scopus, ScienceDirect, OVID, TRIP, and EMBASE using "Galanin" AND "pain" as keywords. Of the 1379 papers that were retrieved in the initial search, we included a total of 141 papers in this review. Using the ARRIVE guidelines, we verified that $89.1 \%$ of the works were of good or moderate quality. Galanin shows a differential role in pain, depending on the pain state, site of action, and concentration. Under normal settings, galanin can modulate nociceptive processing through both a pro- and anti-nociceptive action, in a dose-dependent manner. This peptide also plays a key role in chronic pain conditions and its antinociceptive action at both a spinal and supraspinal level is enhanced, reducing animals' hypersensitivity to both mechanical and thermal stimulation. Our results highlight galanin and its receptors as potential therapeutic targets in pain conditions.
\end{abstract}

Keywords: galanin; galanin receptors; pain; nociception

\section{Introduction}

Chronic pain results from the abnormal function of the nervous system, in which pain persists beyond healing time (more than 3-6 months) [1], and affects approximately $20 \%$ of the European population [2,3]. This abnormal neuronal activity includes the sensitisation of the peripheral and the central nervous systems [4], leading to a heightened perception of pain [5]. However, the molecular mechanisms underlying the maintenance and development of chronic pain are still not fully clarified.

Galanin is a neuroendocrine 29-aminoacid neuropeptide (30 in humans), which was initially discovered by Tatemoto and colleagues [6]. Since then, galanin has been shown to play a key role in several physiological processes such as cognition [7], feeding [8], and nociception [9].

Under normal circumstances, this peptide occurs mostly in the dorsal root ganglia (DRG) [10] and the superficial layers of the spinal dorsal horn [11]. Importantly, it is present in a small population of primary sensory neurons $[12,13]$ that give rise to small diameter fibres shown to co-express the neuropeptides calcitonin gene-related peptide (CGRP) and substance P (SP) $[10,14,15]$. The role of galanin in nociceptive modulation has been intensively investigated using different behavioural and electrophysiological techniques. Under normal conditions, galanin is thought to play a minor role in nociception, however it increases after injury, particularly in the DRG and spinal cord in which it plays a mostly antinociceptive role [16]. In this work, we systematically reviewed the literature regarding the role of galanin and its receptors in nociception at the spinal and supraspinal levels, as well as in the development and maintenance of chronic pain. 


\section{Materials and Methods}

\subsection{Study Design}

This systemic review was conducted according to the Preferred Reporting Items for Systematic Reviews and Meta-Analyses (PRISMA) guidelines [17]. This review's protocol was not registered prior to its submission.

\subsection{Search Strategies}

The literature search was conducted using the following electronic databases: PubMed, Web of Science, Scopus, ScienceDirect, OVID, TRIP and EMBASE. For each database, a combination of search criteria was used: "Galanin" AND "pain" from inception up to 26 July 2021.

\subsection{Eligibility Criteria}

Original articles that evaluated the role of galanin and its receptors in pain were included and divided into two different categories: (i) the role of galanin in nociceptive processing and (iii) changes in the expression of galanin and its receptors in different pain conditions and their role in pain development and maintenance. There was no restriction on the type of pain included in animal models. Publications were excluded when one of the following conditions was fulfilled: (i) non-original publications (reviews and book chapters); (ii) grey literature (conference abstracts, notes, letters to the editor); (iii) studies performed in human subjects; (iv) manuscripts written in languages other than English; and (v) manuscripts dealing with subjects other than pain and galanin (out of the scope).

\subsection{Study Selection}

After removing duplicates, two researchers (DFR and FPR) independently screened the title and abstract of every citation found in the literature search. In a second stage, fulltext papers were screened against the inclusion/exclusion criteria. To qualify for inclusion, both investigators had to reach an agreement. A third investigator was involved in the case of unsolved disagreement (AA).

\subsection{Data Extraction, Management, and Synthesis}

Two researchers conducted the data extraction individually (DFR and FPR), which was posteriorly merged, and the discrepancies in the data extraction were all resolved by consensus. The following data, when available, were extracted from the included studies and compiled in a Microsoft Excel spreadsheet by all authors, including the following information: author, year of publication, species/strain of animals, type of pain studied, animal model, and the results regarding galanin and its receptors. Data from the included studies was synthesised in two tables and a narrative summary of the data is presented in the Results section.

\subsection{Quality Assessment}

Two of the review authors independently assessed the quality of the studies using the ARRIVE guidelines [18], which comprises 21 criteria including study design, sample size, inclusion and exclusion criteria, randomisation in the allocation to experimental units, blinding during the study, outcome measures, statistical methods, description of species and the developmental stage of the animals, reporting of results, scientific background, study objectives, housing conditions, animal care and monitoring, scientific implications of the study, generalisability to other species, protocol registration, ethical approval statement and declaration of interest.

\section{Results}

\subsection{Search Results}

A total of 1379 publication references were initially retrieved using the above-mentioned search strategy (Figure 1) and one additional study was included from the reference lists of included studies using the snowball technique. After the removal of 887 duplicates, 492 pub- 
lications were screened based on titles and abstracts and 460 publications were identified as potentially eligible. After screening the full text, 141 publications were included herein.

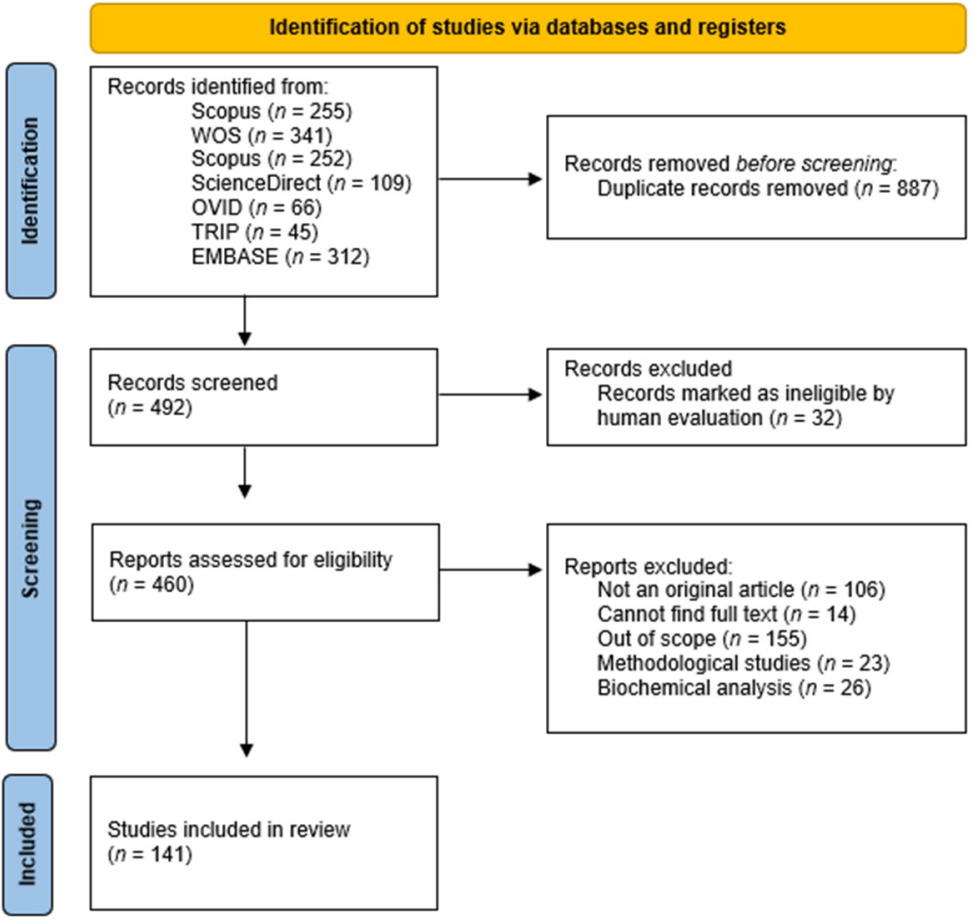

Figure 1. Flowchart representation of the different stages of the selection process.

\subsection{Characteristics of the Included Studies}

A total of 36 articles were included that assessed the role of galanin and its receptors in nociceptive processing in different locations - the spinal cord and peripheral nerves, arcuate nucleus of the hypothalamus (ARC), the central nucleus of the amygdala (CeA), lateral habenula (LHb), nucleus accumbens (NAc) and periaqueductal grey (PAG) - and procedures such as intracerebroventricular administration and galanin overexpression/knockout.

Regarding the role and changes in galanin and its receptors in different animal models of pain, a total of 105 articles were evaluated. While most studies were performed in rodents $(97 \%)$, mostly rats $(70 \%)$, three were performed in monkeys (Macaca mulatta). Different pain models were employed, mostly animal models of inflammatory (24\%) and neuropathic pain $(77 \%)$, such as carrageenan-induced inflammation and peripheral nerve injury, respectively.

\subsection{Assessment of Quality}

Two of the review authors (MJP and FPR) independently assessed the quality of the reporting of the included studies, using the ARRIVE guidelines, as mentioned above. The potential range of the ARRIVE quality score was 0-20 and the overall mean score for the methodological quality of the studies included was $12.4 \pm 2.2$. A score between 0-1 was attributed to each criterion, and the mean score was calculated for each study. A global rating of strong was attributed to studies with a mean score higher than $15(28.4 \%)$, moderate for a score between 10-15 (60.3\%) and weak for those that scored under 10 $(11.3 \%)$. Overall, the quality of the studies was good. The proportion of studies that met each criterion is summarised in the Supplementary Materials Table S1.

\section{The Role of Galanin in Pain Processing at the Spinal and Supraspinal Levels}

The role of galanin in pain processing at the spinal levels has been the subject of many studies since its discovery, in which both endogenous and exogenous galanin are implicated (Tables 1 and S2). 
Table 1. Summary of the literature search on the role of galanin and its receptors in the processing of nociceptive information.

\begin{tabular}{cc}
\hline Mechanism & Effects \\
\hline Endogenous Galanin & $\begin{array}{c}\text { Increase in sensory neurons after administration of resiniferatoxin, an ultrapotent } \\
\text { capsaicin analog [18] }\end{array}$ \\
\hline Galanin Overexpression & $\begin{array}{c}\text { Antinociceptive effect on thermal and mechanical sensitivity [19] } \\
\text { Reduced facilitation of the nociceptive flexor reflex [20] }\end{array}$ \\
\hline
\end{tabular}

GalR1 receptors are located predominantly post-synaptically whereas GalR2 receptors may be localised both pre- and post-synaptically in the spinal cord [21]

Galanin at lower concentrations activates GalR2/R3, whereas galanin at higher concentrations also activates GalR1 [22]

Galanin Receptors

GalR1 activation, but not GalR2/3 activation, suppresses mechanical sensitivity [23] Inactivation of GalR1 attenuates the antinociceptive effect of galanin [24]

GalR1 is an antinociceptive target in the central nucleus of the amygdala $[25,26]$

Selective destruction of GalR1-expressing superficial dorsal horn neurons produces heat hypoalgesia [27]

The absence of GalR2 induces the loss of a subset of sensory neurons (likely nociceptors) [28]

Potentiates the analgesic effect of morphine [29-31]

Interaction between galanin and opioids [32]

Interaction with Opioids

Galanin exerts its antinociceptive effects through the $\mu$-opioid receptor [33]

Both $\mu$ - and $\delta$-opioid receptors are involved in galanin-induced antinociception [34]

Administration of galanin to the saphenous nerve truck inhibits axonal excitability

Local Administration to (antinociceptive effect) [35]

Peripheral Nerves

Administration of galanin to the lumbar splanchnic nerve reduces mechanical sensitivity (antinociceptive effect) [23]

Antinociceptive effect on thermal and mechanical sensitivity [31,36-38]

Antinociceptive effect on formalin-induced nociception [29]

No effect on flexor reflex [30]

Intrathecal Galanin

Reduced facilitation of the nociceptive flexor reflex $[24,39,40]$

Antinociceptive effect mediated by activation of spinal GalR1, but not GalR2 receptors [29]

Antinociceptive effect mediated by activation of GalR2/3 receptors [41]

Intracerebroventricular administration of galanin:

- no effect on mechanical and thermal sensitivity after administration of $\mathrm{N}$-terminal galanin fragment [42]

- antinociceptive effect on thermal and mechanical sensitivity [43-45]

- reduced facilitation of the nociceptive trigemino-hypoglossal reflex $[33,46]$

Galanin administration to the periaqueductal grey (PAG) has an antinociceptive effect on thermal and mechanical sensitivity $[32,47,48]$

Supraspinal Galanin

Activation of GalR1 induces antinociception in rats with morphine tolerance [47]

GalR2 antagonist administration (M871) attenuates the antinociceptive effects of galanin [48]

Galanin administration to the arcuate nucleus of the hypothalamus (ARC) - decreases thermal and mechanical sensitivity $[49,50]$

Galanin administration to the central nucleus of the amygdala (AMY) - decreases thermal and mechanical sensitivity $[25,34]$

Galanin administration to the lateral habenula complex $(\mathrm{LHb})$-decreases thermal and mechanical sensitivity [26]

Wiesenfeld-Hallin and colleagues first demonstrated that intrathecal administration of the putative galanin receptor antagonist M35 (galanin-(1-13)-bradykinin-(2-9)-amide) potentiated the facilitation of the flexor reflex [19]. When applied to peripheral nerves such as the saphenous and lumbar splanchnic nerves, galanin was shown to inhibit their response to noxious stimulation $[20,21]$. Likewise, galanin-over-expressing mice were shown to display reduced facilitation of the flexor reflex after C-fibre stimulation [22], as well as an increased thermal and mechanical nociceptive threshold [23]. Together, these 
results indicate that under normal conditions endogenous galanin plays a suppressing role in nociceptive processing in the spinal cord. However, the mechanisms associated with galanin's inhibitory effect remain unclear, although much evidence points to a postsynaptic action of galanin in the dorsal horn [15], at least in part, mediated by protein kinase C (PKC) [24], and targeting primary afferent terminals to increase the release of substance $\mathrm{P}$ (SP) [25] and oxytocin [26].

The predominant effect of exogenous galanin on nociception is inhibitory, with several behaviour studies showing its intrathecal administration increases the response threshold to both mechanical, thermal, and inflammatory stimulation [25,27-30]. Importantly, exogenous galanin applied at the spinal level displays a biphasic effect upon nociception, potentially acting on primary afferents pre- or post-synaptically. The intrathecal administration of galanin at low doses [31] facilitates the spinal nociceptive flexor effect induced by C-fibre stimulation, and mechanically evoked thresholds of nociceptive afferents [32]. However, at higher doses, galanin produces a dose-dependent inhibition effect, and consequently antinociception, on these same afferents in both mice and rats [32-35]. Such a differential effect of galanin has been suggested to result from activation of different subtypes of receptors, which will be further discussed below.

Galanin and its receptors are also important mediators of nociception and opiateinduced analgesia at the supraspinal level, as they are localised in important nociceptionrelated structures such as the arcuate nucleus of the hypothalamus, the raphe nuclei, the striatum, the ventral hippocampus, and the locus coeruleus [13,36]. Accordingly, several electrophysiological and behavioural studies have been conducted to elucidate the role of galanin in pain modulation in the brain. In the studies included in this review, galanin showed an antinociceptive effect on the response to mechanical and/or thermal stimulation in healthy mice and rats when administered intracerebroventricularly (ICV) [24,37-39]; to the periaqueductal grey matter (PAG), a brain region involved in descending pain modulation [40-42]; to the arcuate nucleus of the hypothalamus (ARC), the major source of $\beta$-endorphin in the brain $[43,44]$; to the nucleus accumbens (NAc), a key structure in modulating rewards and pleasure processing [45]; to the lateral habenular nucleus (LHb), involved in pain-associated depression [46]; and to the central nucleus of the amygdala (CeA), which is primarily associated with emotional processing [47,48]. Additionally, when administered ICV, galanin was shown to display an antinociceptive effect on the trigeminohypoglossal reflex $[49,50]$. Galanin's antinociceptive effect was shown to be modulated by PKC, particularly in the CeA of rodents [51].

\section{Galanin Expression and Modulation in Chronic Pain Models}

Galanin plays an inhibitory role in spinal nociception and this role may be enhanced after peripheral nerve injury or inflammation (Tables 2 and S3, and Figure 2). Indeed, peripheral nerve transection has been shown to dramatically increase galanin expression in primary sensory neurons and their terminals in the spinal cord, which may act to reduce injuryinduced hyperalgesia. Additionally, recent results further point to galanin as a key modulator of nociceptive processing at a supraspinal level, acting on several areas involved not only in the sensory-discriminative aspects but also on motivational-affective responses to pain. 
Table 2. Summary of the literature search on the role of galanin and its receptors in different animal models of experimental pain. (ACC - anterior cingulate cortex; ARC - arcuate nucleus of the hypothalamus; CeA—central nucleus of the amygdala; DRG—dorsal root ganglia; NAc—nucleus accumbens, RVM—rostral ventromedial medulla, TM—tuberomammillary nucleus).

\begin{tabular}{|c|c|}
\hline Mechanism & Effects \\
\hline Galanin Levels_-DRG & $\begin{array}{l}\text { Increased in DRG neurons in animal models of neuropathic pain: } \\
\text { sciatic nerve axotomy [10,15,51-60] } \\
\text { chronic constriction injury of the sciatic nerve [56,61-63] } \\
\text { cisplatin-induced neuropathy [64-67] } \\
\text { alveolar nerve axotomy [68-70] } \\
\text { photochemically induced sciatic nerve injury [71] } \\
\text { spinal nerve ligation [72] } \\
\text { sarcoma-induced cancer pain [73] } \\
\text { varicella zoster virus-induced neuropathy [74] } \\
\text { partial saphenous nerve ligation injury [75] } \\
\text { sciatic nerve pinch [16,76] } \\
\text { tibial nerve injury [77] } \\
\text { median nerve chronic constriction injury [78] } \\
\text { Increased in DRG neurons in animal models of inflammatory pain: } \\
\text { CFA induced arthritis, especially at time-course points with high inflammation and } \\
\text { severe joint destruction [79] } \\
\text { collagen antibody-induced arthritis [80] }\end{array}$ \\
\hline
\end{tabular}
collagen antibody-induced arthritis [80]

Increased in the spinal cord in animal models of neuropathic pain: flexion of inflamed ankles [81]

sciatic nerve axotomy $[53,56,82]$

spinal nerve ligation $[72,83]$

chronic constriction injury of the sciatic nerve $[56,67,84,85]$

Galanin Levels-Spinal noxious colorectal distension [14] sciatic nerve pinch [16] streptozotocin-induced diabetes [76] spinal cord injury [86] Decreased in the spinal cord in animal models of neuropathic pain: cisplatin-induced neuropathy [64] chronic constriction injury of the sciatic nerve [87]

Decreased in the spinal cord at the onset of Freud's adjuvant-induced inflammation, which gradually increases [88]

Increased in the ARC after:

Galanin Levels-Supraspinal

Effect of Galanin Knockout or Overexpression spared nerve injury [89] visceral pain induced by cyclophosphamide (CP) [90] Increase in the RVM and the dorsal raphe nucleus in monoarthritis [91] Increased in the NAc after chronic constriction injury of the sciatic nerve [92]

Decreased in the spinal cord at the onset of Freud's adjuvant-induced inflammation, which gradually increases [88]

No change in spinal galanin levels after collagen antibody-induced arthritis [93] Galanin suppression increases allodynic responses after sciatic nerve axotomy [94] Galanin overexpression decreases thermal/mechanical hyperalgesia after sciatic nerve injury $[94,95]$

Galanin over-expressing animals displayed increased levels of galanin in the DRG and their corresponding nerve terminals after sciatic nerve axotomy [96]

Galanin had a biphasic effect on the flexor reflex in rats with intact nerves, including facilitation, followed by depression, in a dose-dependent manner [97] Intrathecal injections of antibodies against galanin inhibited

Role of Endogenous Galanin carrageenan-induced hyperalgesia [98] M35 administration has a facilitatory effect on flexor reflex excitability, which was potentiated after nerve axotomy [99] 
Table 2. Cont.

Mechanism

Role of Endogenous Galanin

Intrathecal Administration of Galanin
Effects

Intra-arterial infusion of galanin inhibits acetone and menthol responses in the naive rodent and following models of neuropathic (partial sciatic nerve injury) and inflammatory pain (carrageenan) [101]

Intraplantar administration of galanin at low doses increases capsaicin-evoked nociceptive behaviours [102-104]

Reduces carrageenan-induced inflammation and hyperalgesia [105]

Reduced facilitation of the nociceptive flexor reflex after sciatic nerve axotomy [106] Low doses of galanin have a pronociceptive effect on mechanical and cold allodynia after chronic constriction injury of the sciatic nerve [107]

Antinociceptive effect on mechanical/thermal hyperalgesia after:

photochemically-induced sciatic nerve injury [108]

chronic constriction injury of the sciatic nerve [109,110]

kaolin/carrageenan-induced arthritis [111]

spinal nerve ligation [112,113]

carrageenan-induced inflammation [114]

spared nerve injury [115]

sciatic nerve-pinch injury [16,76]

streptozotocin-induced diabetes $[76,116]$

Altered the responses of mechano-nociceptive $\mathrm{C}$-fibre afferents in a dose-dependent manner in both naive and nerve-injured animals, with low concentrations facilitating and high markedly inhibiting mechano-nociceptor activity [117]

Decreased expression of GalR1 after in DRG and spinal cord neurons: carrageenan-induced inflammation [118]

sciatic nerve axotomy $[118,119]$

streptozotocin-induced diabetes $[76,116]$

spinal nerve ligation [120]

sciatic nerve pinch injury [76]

GalR1 knockout animals display increased mechanical and thermal hypersensitivity after sciatic nerve injury [121]

GalR1 knockout mice have no differences concerning acute nociception but showed a modest tendency towards increased hyperalgesia after tissue injury

and inflammation [122]

Activation of GalR1 reduces CAP-induced inflammatory pain, while the opposite is observed after activation of GalR2 [104]

The modulatory effects of galanin on cooling are independent of GalR2 and GalR3 activation but mediated by activation of GalR1 [101].

Activation of GalR1, but not GalR2, attenuated diabetic neuropathic pain [116]

GalR1 activation results in the inhibition of the PKA and induces antinociceptive

effects after chronic constriction injury of the sciatic nerve [123]

Increased expression of GalR2 in DRG and spinal cord neurons after:

carrageenan-induced inflammation [118]

sciatic nerve pinch injury [76]

median nerve chronic constriction injury [78]

spared nerve injury [124]

Decreased expression of GalR2 in DRG and spinal cord neurons after:

sciatic nerve axotomy [118,119]

streptozotocin-induced diabetes $[76,116]$

spinal cord injury [86]

alveolar nerve axotomy [70]

Lack of the GalR2 results in a considerable developmental loss of DRG neurons after spinal nerve injury [125] and sciatic nerve axotomy [126]

Activation of GalR2 has an antinociceptive effect after nerve injury

and inflammation [127]

A low dose of galanin has a pronociceptive role at the spinal cord level, which is mediated by GalR2 receptors whereas the antiallodynic effect of high-dose galanin on neuropathic pain is mediated by the GalR1 receptors [107] 
Table 2. Cont.

\begin{tabular}{ll}
\hline Mechanism & \multicolumn{1}{c}{ Effects } \\
\hline & Increased expression of GalR1 and GalR2 in the NAc after: \\
& carrageenan-induced inflammation [128] \\
chronic constriction injury of the sciatic nerve [128,129] & GalR2 activation in the NAc induces CAMKII and PKC after \\
Role of Galanin & carrageenan-induced inflammation [130] \\
Receptors & Increased expression of GalR1 in the CeA after chronic constriction injury of the \\
& sciatic nerve [131] \\
& Increased expression of GalR1 in the TM after chronic constriction injury of the \\
& sciatic nerve [132] \\
& GalR2 is involved in the galanin-induced antinociception in the ACC [119,133] \\
& GalR3 does not mediate mechanical hyperalgesia in autoimmune arthritis [119]
\end{tabular}

GalR3 does not mediate mechanical hyperalgesia in autoimmune arthritis [119]

Galanin administration to the PAG decreases mechanical and thermal hyperalgesia after chronic constriction injury of the sciatic nerve [134]

Galanin administration to the ARC decreases mechanical and thermal

hyperalgesia after:

carrageenan-induced inflammation [135]

sciatic nerve ligation [136]

Galanin administration to the TM decreases mechanical and thermal hyperalgesia after carrageenan-induced inflammation and chronic constriction injury of the sciatic nerve [132]

Galanin administration of galanin to the dorsomedial hypothalamic nucleus is pronociceptive in awake healthy and kaolin/carrageenan-arthritic animals [91]

Supraspinal Administration of Galanin Galanin administration to the NAc decreases mechanical and thermal

hyperalgesia after:

carrageenan-induced inflammation [137]

chronic constriction injury of the sciatic nerve [92,128]

Administration of M35 in the NAc attenuated the antinociceptive effects of galanin after chronic constriction injury of the sciatic nerve [123]

Galanin administration to the ACC decreases mechanical/thermal hyperalgesia after: carrageenan-induced inflammation [138]

chronic constriction injury of the sciatic nerve [133]

Galanin administration to the CeA decreases mechanical/thermal hyperalgesia after chronic constriction injury of the sciatic nerve [131]

Subarachnoid transplantation of immortalised galanin-over-expressing astrocytes has an antinociceptive effect after spared nerve injury [139]

Interaction with opioids

Galanin acts synergically with opioids to inhibit the nociceptive information transmission in animal models of chronic constriction injury of the sciatic nerve $[134,140,141]$

\subsection{Endogenous Galanin}

Endogenous galanin plays a critical role in the development of hyperalgesia following peripheral injury, and as such is required for the development of peripheral and central sensitisation. This nociceptive role has been further confirmed by the development of knockout and transgenic animals. Galanin knockout animals are hyper-responsive to noxious stimulation after both carrageenan-induced inflammation [142] and peripheral nerve injury $[75,107]$. The opposite is observed in galanin-over-expressing mice, which display decreased hyperalgesia/allodynic responses and increased recovery after peripheral nerve injury [94,95]. As well, galanin administered systemically was able to reduce mechanical and thermal hyperalgesia (cold) in both inflammation and peripheral injury animal models [101].

\subsection{Primary Sensory Neurons and Dorsal Root Ganglia (DRG)}

In primary sensory neurons, galanin levels increase from non-detectable levels after chronic constriction injury of the sciatic nerve [61]. However, this protective mechanism does not appear to be based on changes in galanin expression in injured primary 
neurons [100]. A possibility is that nerve injury interrupts the anterograde transport of neuropeptides from the DRGs to the spinal cord, causing an accumulation of galanin.

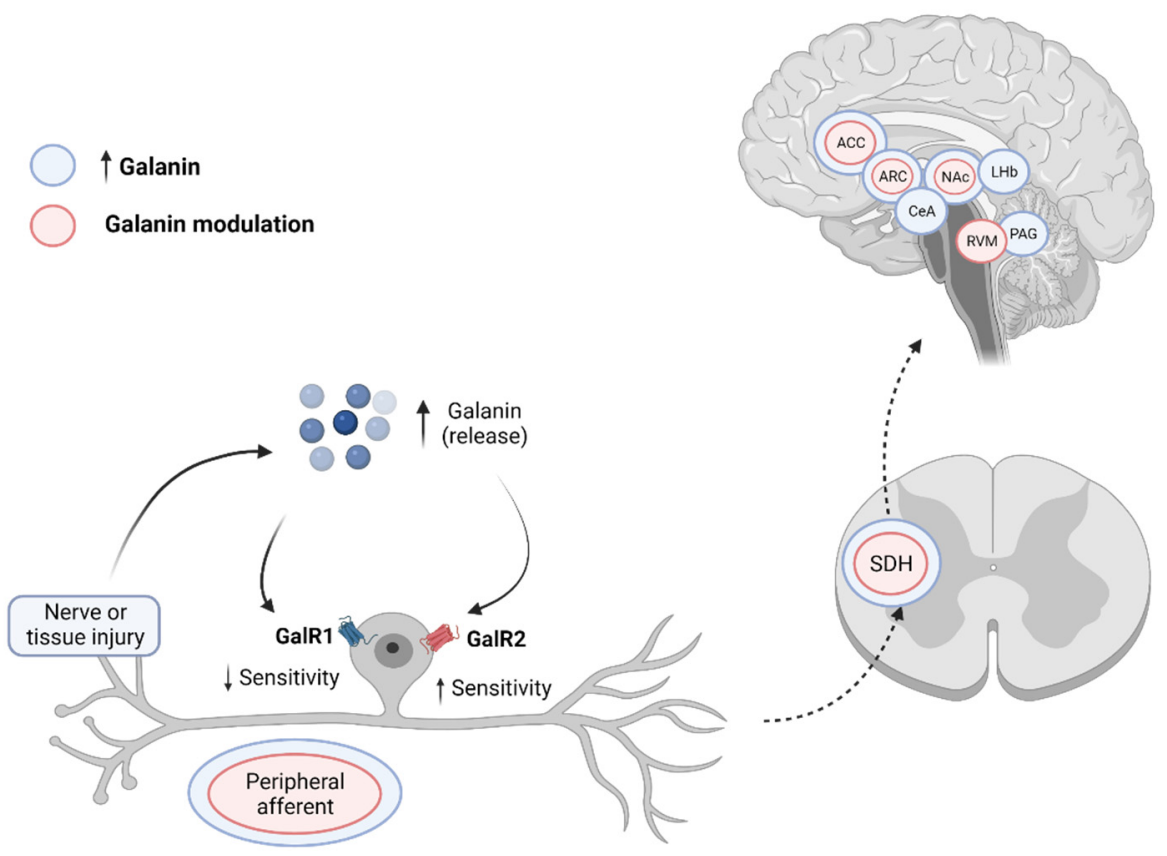

Figure 2. Mechanism of action of galanin in chronic pain conditions. Under normal situations, peripheral nerve injury or inflammation induces an increase in galanin levels that act upon GalR1 receptors, inhibiting nociceptive transmission. In chronic pain conditions, there is an upregulation of GalR2 receptors in peripheral nerve afferents and their correspondent dorsal root ganglia (DRG), which causes hypersensitivity to noxious stimulation and consequent mechanical and thermal hyperalgesia. Peripheral injury was also shown to increase galanin levels at both a spinal and supraspinal level, and its administration produces an antinociceptive effect upon nociceptive processing. (ACC-anterior cingulate cortex; ARC — arcuate nucleus of the hypothalamus; CeA—central nucleus of the amygdala; LHb-lateral habenula; NAc—nucleus accumbens; PAG—periaqueductal gray; RVM-rostral ventromedial medulla; SDH—spinal dorsal horn). Created in BioRender.com.

The administration of galanin into the receptive fields of sensory fibres inhibited the response of dorsal horn neurons after spinal nerve ligation [113]. Additionally, after axotomy of the sciatic nerve, blocking galanin action by the administration of M-35 [99], a potent galanin antagonist, or antisense nucleotides [143] to the injured nerve potentiated the flexor reflex excitability [106] and increased autotomy behaviour in axotomised animals, suggesting a protective role of galanin after peripheral nerve injury. Similarly, the intraarticular administration of the antagonist M-35 doubled the responses to noxious stimuli in rats with kaolin/carrageenan-induced inflammation [144]. However, at low doses, the intra-plantar administration of galanin displayed a pronociceptive effect in capsaicinevoked inflammatory pain, mediated by the activation of GalR2 receptors [102,104], and consequently, the PKC intracellular signalling pathway [103].

After peripheral axotomy, galanin is dramatically upregulated and expressed in small-sized DRG neurons, with a shift towards its expression also in medium/largesized neurons $[10,51,53-58,96,111,145]$, both of which are accompanied by a retrograde increase in galanin in the spinal cord. Similar results were obtained after partial sciatic nerve ligation [59,145,146], cisplatin-induced neuronopathy [64], spinal nerve ligation [72], constriction/photochemically-induced sciatic nerve injury $[62,63,65-67,71,76]$, in inferior alveolar neuromas [68,69], tibial nerve injury [51,77,147], diabetes-induced neuropathy [76], medial nerve injury [78], trigeminal nerve injury [70], Freud's adjuvant-induced inflammation [79,145], collagen-induced arthritis [80], bone cancer [73], post-herpetic neuralgia [74] and HIV-associated neuropathic pain [148]. 
This increase in galanin levels could be possibly due to an augmented galanin synthesis or decreased release, causing its accumulation in the somata of sensory neurons. Interestingly, a study by Ma and Bisby [56] showed this increase is significantly higher in constriction and partial nerve transection models, in comparison with total axotomy of the sciatic nerve. Conceivably, as during both chronic constriction and partial nerve transection, the surviving axons share an environment where adjacent axons are undergoing Wallerian degeneration, this setting might modulate galanin expression in both spared and axotomised DRG neurons. Indeed, different molecules such as leukaemia inhibitory factor (LIF) [55], acidic and basic fibroblast growth factor (aFGF, bFGF), nerve growth factor (NGF) [54], glial cell line-derived neurotrophic factor (GDNF) [72] and glial nuclear factor kappa B (NF-kB) [67] were shown to be key modulators of severe galanin upregulation observed after nerve injury.

\subsection{Spinal Dorsal Horn (SDH)}

The results in the literature are contradictory in regard to the SDH. An increase of galanin levels in the spinal cord was detected in spinal nerve ligation and injury models $[72,86]$, particularly in glial cells and their processes [83], as well as in small and medium-sized neurons of the dorsal horn with increased branching after axotomy [51,60,149]. Similarly, after noxious colorectal distension (CRD), the spinal levels of galanin increased gradually and

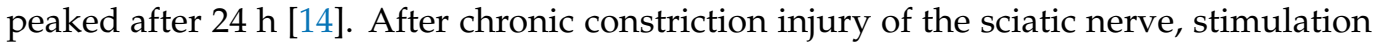
of the nerve was shown to increase galanin immunoreactivity in the spinal cord, which originated in primary afferent neurons [84]. However, this effect was not persistent and a decrease in galanin was observed in the weeks following injury [87]. Interestingly, increased levels of galanin were observed in the gracile nuclei after sciatic nerve injury $[53,56,82]$, suggesting that some of the inhibitory effects of galanin may be mediated through the gracile nucleus pathway. The opposite was observed immediately after Freud's adjuvantinduced inflammation, as galanin levels initially decreased $[81,88]$, but as inflammation progressed, its content gradually increased, and galanin levels normalised [88]. A possible explanation for the initial decrease could be that noxious stimulation depletes the cellular stores of releasable galanin, and consequently, basal levels decrease below those present before any stimulation.

Galanin administered at the spinal level inhibited the activity of wide-dynamic-range neurons in a dose-dependent manner [110] and the response of SDH neurons to mechanical, thermal and electrical stimulation after spinal nerve ligation [112]. Similarly, in chronic pain animal models, intrathecal galanin decreased mechanical and thermal hyperalgesia after carrageenan-induced inflammation [105], kaolin/carrageenan-induced arthritis [144], chronic constriction injury of the sciatic nerve $[109,150]$, photochemically-induced nerve injury [108] and sciatic nerve-pinch injury [16,76] and diabetes-induced neuropathy [76]. Additionally, spinal administration of galanin reduced the endogenous levels of galanin in the DRGs and the dorsal horn after sciatic nerve pinch and diabetes-induced neuropathy [76]. These data suggest an antinociceptive role of galanin, which together with the fact that galantide administration increased the activity of wide-dynamic-range neurons [110], explains the increased autotomy observed after administration of galanin [99,106,143].

\subsection{Supraspinal Galanin}

An antinociceptive role of exogenous galanin has been recently demonstrated at the supraspinal level, particularly in the ARC and PAG. An increase in galanin expression in the ARC after nerve injury has been demonstrated in spared nerve injury [89] and cyclophosphamide (CP)-induced cystitis [90] animal models. Additionally, the administration of galanin to this area reduced mechanical and thermal hyperalgesia after carrageenaninduced inflammation [135] and chronic constriction injury of the sciatic nerve [136], with an increase in the number of galaninergic neurons. Galanin administration to the PAG also had an analgesic effect after chronic constriction injury of the sciatic nerve [134]. Indeed, galanin was shown to activate the beta-endorphinergic pathway from the ARC 
to the PAG [50], resulting in increased levels of serotonin [151] and galanin [90] in the medulla. Accordingly, it has been proposed that galanin regulates the excitability of the $\beta$-endorphinergic neurons in the ARC, and thereby the release of $\beta$-endorphin in the PAG [50]. Moreover, as most of the ARC neurons are projecting neurons, it is also possible that exogenous galanin acts through galaninergic projecting neurons.

Galanin was also shown to be involved in pain modulation in several other brain areas, as the administration of galanin reduced mechanical and thermal hyperalgesia when administered to (i) the medulla after spared nerve injury [115]; (ii) the NAc, after carrageenan-induced inflammation [137] and chronic constriction injury of the sciatic nerve [92] in a dose-dependent manner, an effect blocked by galantide [92]; (iii) the CeA, after chronic constriction injury of the sciatic nerve [131]; (iv) the ACC after carrageenaninduced inflammation, in which an increased expression of galanin was observed [138]; and (v) the tuberomammillary nucleus of the hypothalamus after inflammation and chronic constriction injury of the sciatic nerve [132], an effect also blocked by galantide. Additionally, the subarachnoid transplantation of immortalised galanin-over-expressing astrocytes was shown to reduce mechanical and thermal hyperalgesia after spared nerve injury [139].

\section{Receptor Mechanisms Underlying the Varying Roles of Galanin}

Galanin acts through three main receptors: galanin receptor 1 (GalR1), galanin receptor 2 (GalR2) and galanin receptor 3 (GalR3), all belonging to the family of G-protein coupled receptors (GPCR). These galanin receptors are differentially distributed, and all three are present in DRGs and the spinal cord [152].

The first known galanin receptor, GalR1, is the most abundant and widespread in the CNS of adult rodents [153], and GalR1 mRNA was found in many brain areas such as the hippocampus, amygdala, ventral tegmental area (VTA) and the NAc [154]. GalR1 receptors are located predominantly post-synaptically [21], and the presence of GalR1 in DRG, the SDH and primary afferents suggest an antinociceptive effect upon primary afferent terminal excitability [27,29]. Indeed, the inactivation [24], reduction in GalR1 levels [41], or GalR1-knockout [121,122] causes a partial blockade of the inhibitory effect of galanin, increasing the mechanical and thermal hypersensitivity. The selective destruction of GalR1-expressing neurons in the SDH also reduced thermal sensitivity to heat (46). GalR1 is also an important player in galanin-induced antinociceptive effects in the brain. Accordingly, the administration of M617, a selective agonist to GalR1 [155], was shown to cause a decrease in the sensitivity to both thermal and mechanical stimulation when administrated intracerebroventricularly [45], to the CeA $[25,128,131]$ and the PAG of rats [26]. The activation of GalR1 was further shown to inhibit protein kinase A (PKA), particularly in the CeA of rodents, with an antinociceptive role after nerve injury [123]. These results further support the notion that galanin induces antinociception in rodents through activation of GalR1 receptors at both the spinal and supraspinal level.

GalR2 is mostly expressed in DRGs and brain areas such as the hippocampus, cerebellar cortex, hypothalamus, and amygdala [156]. GalR2 receptors are localised both pre- and post-synaptically [21]. The activation of GalR2 suppresses $\mathrm{Ca}^{2+}$ channel currents [21], and consequently increases the content of $\mathrm{Ca}^{2+}$ [153], which could further activate CAMKII [130] and MAPK [157], thus modulating nociception and neuroplasticity. Additionally, GalR2 activation was shown to enhance NPYY1R-mediated signalling [158], which leads to increased anxiety-like behaviours, and could possibly be altered in pain modulatory areas. These receptors are associated with a more pronociceptive action of galanin, as the selective destruction of GalR2-expressing neurons causes the loss of a subset of sensory neurons in the DRG (likely nociceptors) and reduces neuropathic and inflammatory pain responses [27]. This phenomenon was also observed after axotomy, although with no apparent impact on the mechanical and thermal nociceptive responses [125]. Further evidence of a pronociceptive role of GalR2 was demonstrated when intraplantar administration of GalR2 agonist M1896 increased mechanical and thermal nociceptive responses after chronic constriction injury of the median nerve, with GalR2 antagonist M871 having an opposite effect [78]. 
However, different results were obtained after administration of a GalR2-preferring galanin analogue, which displayed an analgesic effect after carrageenan-induced induction and partial sciatic nerve ligation [127]. There are few reports regarding the role of GalR2 in pain modulation in the brain. Nonetheless, GalR2 was shown to be involved in galanin-induced antinociception at the supraspinal level, as the administration of M871 to the PAG [48], the NAc [129,130] and the ACC [138] attenuated the antinociceptive effects of galanin.

The distribution of GalR3 in the central nervous system is rather restricted when compared to GalR1 and GalR2, being present primarily in the preoptic/hypothalamic area [159]. Although the mechanisms of GalR3 are still largely unknown, this receptor is expressed on murine neutrophils and has been shown to influence the vascular components of inflammatory processes. Indeed, recent studies showed that GalR3 knockout animals display increased disease severity and oedema after autoimmune arthritis [119], suggesting a mainly anti-inflammatory role for this receptor.

After inflammation or nerve injury, galanin receptors GalR1 and GalR2 show great expression plasticity at the spinal, the DRG, and the supraspinal levels. After peripheral nerve injury and inflammation, GalR1 was downregulated $[16,76,120]$ while GalR2 was upregulated $[16,76,78,118,124,126]$ in both the DRG and SDH. These results are consistent with a more pronociceptive action of GalR2 in the spinal cord, causing hypersensitivity to noxious stimulation and the consequent mechanical and thermal hyperalgesia observed in these animals. Yet, in spinal cord injury [86], trigeminal nerve injury [70] and streptozotocininduced diabetes [116], GalR2 expression in DRG decreased as well as both receptors expression in the dorsal horn, suggesting a different mechanistic action of galanin and its receptors in these pathologies. At the supraspinal level, an increased expression of both GalR1 and GalR2 receptors was observed in the tuberomammillary nucleus (TM) [132], the NAc [128,137] and the ACC [138] in inflammatory and nerve injury animal models.

The differences between receptor subtypes contribute to the diversity of the possible physiological effects and the pharmacological relevance of galanin in nociception and pain. It was proposed that galanin displays a biphasic and dose-dependent effect on nociception, through the action of inhibitory (antinociceptive) GalR1 receptors or excitatory (pronociceptive) GalR2 receptors [82,160]. Indeed, a low dose of galanin has a pronociceptive role at the spinal level, which was shown to be mediated by GalR2 receptors, whereas at higher doses, the antinociceptive role of galanin is mediated by GalR1 [82]. Different mechanisms have been suggested for this dual role of galanin receptors in nociception. In the substantia gelatinosa (SG), galanin at lower concentrations was shown to enhance the release of Lglutamate from nerve terminals onto SG neurons by activating GalR2/R3, whereas galanin at higher concentrations produced membrane hyperpolarisation by activating GalR1 [22].

\section{Other Mechanisms}

Considering the direct antinociceptive effect of opioid analgesics, the clinical application of epidural or intrathecal morphine for pain relief is a common medical procedure. However, morphine is a potent inducer of tolerance and dependence. To reduce the effective dose of opioids and their consequent adverse effects, different attempts have been made to combine morphine with other receptor agonists such as galanin.

Galanin can act synergistically with opiates to suppress spinal hyperexcitability, being a potential target for the management of patients suffering from chronic pain, particularly when combined with morphine. Intrathecal administration of galanin reduced the morphine dose required for the suppression of the flexor reflex [97], and the further administration of the galanin antagonists' galantide and M-35 almost completely abolished the antinociceptive effect of morphine [31]. This interaction is mediated mostly by mu-opioid receptors [141], which are significantly increased after nerve injury [161]. Accordingly, after binding to mu-opioid receptors, galanin may facilitate the inhibitory effects of opioid peptides, and/or enhance their affinity with their receptors. The administration of galanin receptor antagonists prevents galanin from binding to its receptors and indirectly attenuates the analgesic effect of opioids. 
Galanin was also shown to interact with opioid actions in the brain, particularly in the CeA, ARC and the PAG. The injection of galanin ICV [42] or directly into these areas [34,134] potentiated the action of morphine, and its antinociceptive effect was reversed by opioid receptor antagonists, namely, non-selective naloxone and $\mu$-selective $\beta$-FNA [33,47]. This interaction between galanin and opioid receptors occurs via the neural pathway from the ARC to the PAG [33] and is mediated by the excitatory GalR2 receptors [47].

\section{Conclusions}

This review not only indicates that galanin has a mostly antinociceptive role at both the spinal and supraspinal levels, but also suggests a possible interaction between galanin and the endogenous opioid system. Since chronic pain could develop from insufficient galaninergic control of nociception, targeting galanin receptors (particularly GalR1) could therefore be a potential therapeutic strategy, especially when paired with opioids.

Supplementary Materials: The following supporting information can be downloaded at: https: / www. mdpi.com/article/10.3390/cells11050839/s1, Table S1: Summary of the methodological quality of the included studies, assessed using the ARRIVE guidelines for the reporting of in vivo experiments; Table S2: Summary of the literature search on the role of galanin and its receptors in the processing of nociceptive information; Table S3: Summary of the literature search on the role of galanin and its receptors in different animal models of chronic pain.

Author Contributions: Conceptualisation, A.A. and F.P.-R.; methodology, D.F.-R. and F.P.-R.; formal analysis, D.F.-R.; data curation, D.F.-R. and F.P.-R.; writing-original draft preparation, D.F.-R.; writing-review and editing, F.P.-R. and A.A.; supervision, A.A.; project administration, F.P.-R. and A.A.; funding acquisition, F.P.-R. and A.A. All authors have read and agreed to the published version of the manuscript.

Funding: This work was funded by National funds, through the Foundation for Science and Technology (FCT) — project UIDB/50026/2020 and UIDP/50026/2020. Diana Fonseca-Rodrigues was supported by FCT grant 2021.04741.BD.

Institutional Review Board Statement: Not applicable.

Informed Consent Statement: Not applicable.

Data Availability Statement: The data underlying this article are available in the article and the online Supplementary Material.

Acknowledgments: Figure 2 was created using BioRender.com.

Conflicts of Interest: The authors declare no conflict of interest.

\section{References}

1. Treede, R.D.; Rief, W.; Barke, A.; Aziz, Q.; Bennett, M.I.; Benoliel, R.; Cohen, M.; Evers, S.; Finnerup, N.B.; First, M.B.; et al. A classification of chronic pain for ICD-11. Pain 2015, 156, 1003-1007. [CrossRef]

2. Goldberg, D.S.; McGee, S.J. Pain as a global public health priority. BMC Public Health 2011, 11, 770. [CrossRef] [PubMed]

3. Breivik, H.; Collett, B.; Ventafridda, V.; Cohen, R.; Gallacher, D. Survey of chronic pain in Europe: Prevalence, impact on daily life, and treatment. Eur. J. Pain 2006, 10, 287. [CrossRef] [PubMed]

4. Woolf, C.J. Central sensitization: Implications for the diagnosis and treatment of pain. Pain 2011, 152, 1-31. [CrossRef] [PubMed]

5. Bykov, Y.; Wagner, S.; Walter, O.; Döring, M.; Fischer, O.; Pospiech, D.; Köppl, T.; Altstädt, V. Synthesis of new DOPO conatining DIols based on diethanolamine. Heteroat. Chem. 2011, 6, 2873-2877. [CrossRef]

6. Tatemoto, K.; Rökaeus, Å.; Jörnvall, H.; McDonald, T.J.; Mutt, V. Galanin-A novel biologically active peptide from porcine intestine. FEBS Lett. 1983, 164, 124-128. [CrossRef]

7. Crawley, J.N. Galanin impairs cognitive abilities in rodents: Relevance to Alzheimer's disease. Cell. Mol. Life Sci. 2008, 65, 1836-1841. [CrossRef]

8. Barson, J.R.; Morganstern, I.; Leibowitz, S.F. Galanin and consummatory behavior: Special relationship with dietary fat, alcohol and circulating lipids. EXS 2010, 102, 87-111. [CrossRef] [PubMed]

9. Xu, X.J.; Hökfelt, T.; Wiesenfeld-Hallin, Z. Galanin and spinal pain mechanisms: Where do we stand in 2008? Cell. Mol. Life Sci. 2008, 65, 1813-1819. [CrossRef] [PubMed]

10. Zhang, X.; Ju, G.; Elde, R.; Hökfelt, T. Effect of peripheral nerve cut on neuropeptides in dorsal root ganglia and the spinal cord of monkey with special reference to galanin. J. Neurocytol. 1993, 22, 342-381. [CrossRef] 
11. Melander, T.; Hökfelt, T.; Rökaeus, A. Distribution of galaninlike immunoreactivity in the rat central nervous system. J. Comp. Neurol. 1986, 248, 475-517. [CrossRef] [PubMed]

12. Skofitsch, G.; Jacobowitz, D.M. Galanin-like immunoreactivity in capsaicin sensitive sensory neurons and ganglia. Brain Res. Bull. 1985, 15, 191-195. [CrossRef]

13. Ch'ng, J.L.C.; Christofides, N.D.; Anand, P.; Gibson, S.J.; Allen, Y.S.; Su, H.C.; Tatemoto, K.; Morrison, J.F.B.; Polak, J.M.; Bloom, S.R. Distribution of galanin immunoreactivity in the central nervous system and the responses of galanin-containing neuronal pathways to injury. Neuroscience 1985, 16, 343-354. [CrossRef]

14. Lu, C.L.; Pasricha, P.J.; Hsieh, J.C.; Lu, R.H.; Lai, C.R.; Wu, L.L.; Chang, F.Y.; Lee, S.D. Changes of the neuropeptides content and gene expression in spinal cord and dorsal root ganglion after noxious colorectal distension. Regul. Pept. 2005, 131, 66-73. [CrossRef] [PubMed]

15. Xu, Z.Q.; Shi, T.J.; Landry, M.; Hökfelt, T. Evidence for galanin receptors in primary sensory neurones and effect of axotomy and inflammation. Neuroreport 1997, 8, 237-242. [CrossRef]

16. Xu, X.; Yang, X.; Zhang, P.; Chen, X.; Liu, H.; Li, Z. Effects of exogenous galanin on neuropathic pain state and change of galanin and its receptors in DRG and SDH after sciatic nerve-pinch injury in rat. PLoS ONE 2012, 7, e0037621. [CrossRef]

17. Moher, D.; Liberati, A.; Tetzlaff, J.; Altman, D.G. Preferred reporting items for systematic reviews and meta-analyses: The PRISMA statement. J. Clin. Epidemiol. 2009, 62, 1006-1012. [CrossRef]

18. Xu, X.J.; Farkas-Szallasi, T.; Lundberg, J.M.; Hökfelt, T.; Wiesenfeld-Hallin, Z.; Szallasi, A. Effects of the capsaicin analogue resiniferatoxin on spinal nociceptive mechanisms in the rat: Behavioral, electrophysiological and in situ hybridization studies. Brain Res. 1997, 752, 52-60. [CrossRef]

19. Blakeman, K.H.; Holmberg, K.; Hao, J.X.; Xu, X.J.; Kahl, U.; Lendahl, U.; Bartfai, T.; Wiesenfeld-Hallin, Z.; Hökfelt, T. Mice over-expressing galanin have elevated heat nociceptive threshold. Neuroreport 2001, 12, 423-425. [CrossRef]

20. Grass, S.; Crawley, J.N.; Xu, X.J.; Wiesenfeld-Hallin, Z. Reduced spinal cord sensitization to C-fibre stimulation in mice overexpressing galanin. Eur. J. Neurosci. 2003, 17, 1829-1832. [CrossRef]

21. Alier, K.A.; Chen, Y.; Sollenberg, U.E.; Langel, Ü.; Smith, P.A. Selective stimulation of GalR1 and GalR2 in rat substantia gelatinosa reveals a cellular basis for the anti- and pro-nociceptive actions of galanin. Pain 2008, 137, 138-146. [CrossRef] [PubMed]

22. Yue, H.Y.; Fujita, T.; Kumamoto, E. Biphasic modulation by galanin of excitatory synaptic transmission in substantia gelatinosa neurons of adult rat spinal cord slices. J. Neurophysiol. 2011, 105, 2337-2349. [CrossRef] [PubMed]

23. Taylor, T.S.; Konda, P.; John, S.S.; Bulmer, D.C.; Hockley, J.R.F.; Smith, E.S.J. Galanin suppresses visceral afferent responses to noxious mechanical and inflammatory stimuli. Physiol. Rep. 2020, 8, 1-14. [CrossRef] [PubMed]

24. Rezaei, K.; Xu, I.S.; Wu, W.P.; Shi, T.J.; Soomets, U.; Land, T.; Xu, X.J.; Wiesenfeld-Hallin, Z.; Hökfelt, T.; Bartfai, T.; et al. Intrathecal administration of PNA targeting galanin receptor reduces galanin-mediated inhibitory effect in the rat spinal cord. Neuroreport 2001, 12, 317-320. [CrossRef]

25. Li, J.; Zhang, J.J.; Xu, S.L.; Yu, L.C. Antinociceptive effects induced by injection of the galanin receptor 1 agonist M617 into central nucleus of amygdala in rats. Neurosci. Lett. 2012, 526, 45-48. [CrossRef]

26. Fu, L.B.; Wang, Y.; Sun, X.X.; Liu, X.X.; Wang, Y.; Zhuang, W. Antinociceptive effects induced by intra-lateral habenula complex injection of the galanin receptor 1 agonist M617 in rats. Exp. Brain Res. 2016, 234, 493-497. [CrossRef]

27. Lemons, L.L.; Wiley, R.G. Galanin receptor-expressing dorsal horn neurons: Role in nociception. Neuropeptides 2011, 45, 377-383. [CrossRef]

28. Hobson, S.A.; Holmes, F.E.; Kerr, N.C.H.; Pope, R.J.P.; Wynick, D. Mice deficient for galanin receptor 2 have decreased neurite outgrowth from adult sensory neurons and impaired pain-like behaviour. J. Neurochem. 2006, 99, 1000-1010. [CrossRef]

29. Hua, X.Y.; Hayes, C.S.; Hofer, A.; Fitzsimmons, B.; Kilk, K.; Langel, Ü.; Bartfai, T.; Yaksh, T.L. Galanin Acts at GalR1 Receptors in Spinal Antinociception: Synergy with Morphine and AP-5. J. Pharmacol. Exp. Ther. 2004, 308, 574-582. [CrossRef]

30. Wiesenfeld-Hallin, Z.; Xu, X.J.; Villar, M.J.; Hökfelt, T. Intrathecal galanin potentiates the spinal analgesic effect of morphine: Electrophysiological and behavioural studies. Neurosci. Lett. 1990, 109, 217-221. [CrossRef]

31. Reimann, W.; Englberger, W.; Friderichs, E.; Selve, N.; Wilffert, B. Spinal antinociception by morphine in rats is antagonised by galanin receptor antagonists. Naunyn-Schmiedebergs Arch. Pharmacol. 1994, 350, 380-386. [CrossRef] [PubMed]

32. Wang, D.; Ye, H.H.; Yu, L.C.; Lundeberg, T. Intra-periaqueductal grey injection of galanin increases the nociceptive response latency in rats, an effect reversed by naloxone. Brain Res. 1999, 834, 152-154. [CrossRef]

33. Zubrzycka, M.; Janecka, A. Interactions of galanin with endomorphin-2, vasopressin and oxytocin in nociceptive modulation of the trigemino-hypoglossal reflex in rats. Physiol. Res. 2008, 57, 769-776. [CrossRef]

34. Jin, W.Y.; Liu, Z.; Liu, D.; Yu, L.C. Antinociceptive effects of galanin in the central nucleus of amygdala of rats, an involvement of opioid receptors. Brain Res. 2010, 1320, 16-21. [CrossRef] [PubMed]

35. Hulse, R.P. Identification of mechano-sensitive $C$ fibre sensitization and contribution to nerve injury-induced mechanical hyperalgesia. Eur. J. Pain 2016, 20, 615-625. [CrossRef] [PubMed]

36. Post, C.; Alari, L.; Hokfelt, T. Intrathecal galanin increases the latency in the tail-flick and hot-plate tests in mouse. Acta Physiol. Scand. 1988, 132, 583-584. [CrossRef]

37. Kuraishi, Y.; Kawabata, S.; Matsumoto, T.; Nakamura, A.; Fujita, H.; Satoh, M. Involvement of substance P in hyperalgesia induced by intrathecal galanin. Neurosci. Res. 1991, 11, 276-285. [CrossRef] 
38. Wiesenfeld-Hallin, Z.; Xu, X.-J.; Hao, J.-X.; Hokfelt, T. The behavioural effects of intrathecal galanin on tests of thermal and mechanical nociception in the rat. Acta Physiol. Scand. 1993, 147, 457-458. [CrossRef]

39. Xu, X.J.; Wiesenfeld-Hallin, Z.; Hökfelt, T. Intrathecal galanin blocks the prolonged increase in spinal cord flexor reflex excitability induced by conditioning stimulation of unmyelinated muscle afferents in the rat. Brain Res. 1991, 541, 350-353. [CrossRef]

40. Xu, I.S.; Grass, S.; Xu, X.J.; Wiesenfeld-Hallin, Z. On the role of galanin in mediating spinal flexor reflex excitability in inflammation. Neuroscience 1998, 85, 827-835. [CrossRef]

41. Grass, S.; Jacoby, A.S.; Iismaa, T.P.; Crawley, J.N.; Xu, X.J.; Wiesenfeld-Hallin, Z. Flexor reflex excitability in mice lacking galanin receptor galanin-R1. Neurosci. Lett. 2003, 345, 153-156. [CrossRef]

42. Przewłocka, B.; Machelska, H.; Rekowski, P.; Kupryszewski, G.; Przewłocki, R. Intracerebroventricular galanin and N-terminal galanin fragment enhance the morphine-induced analgesia in the rat. J. Neural Transm. 1995, 102, 229-235. [CrossRef] [PubMed]

43. $\mathrm{Wu}, \mathrm{X}$; $\mathrm{Yu}, \mathrm{L} . \mathrm{C}$. Alternation of galanin in nociceptive modulation in the central nervous system of rats during morphine tolerance: A behavioral and immunohistochemical study. Brain Res. 2006, 1086, 85-91. [CrossRef] [PubMed]

44. Fu, L.B.; Wang, X.B.; Jiao, S.; Wu, X.; Yu, L.C. Antinociceptive effects of intracerebroventricular injection of the galanin receptor 1 agonist M 617 in rats. Neurosci. Lett. 2011, 491, 174-176. [CrossRef]

45. Shi, J.; Fu, L.B.; Yu, L.C. Involvement of protein kinase C in the galanin-induced antinociception in the brain of rats. Neurosci. Lett. 2011, 497, 60-63. [CrossRef]

46. Zubrzycka, M.; Janecka, A. Effect of galanin on substance P- and vasoactive intestinal polypeptide-induced nociceptive trigeminohypoglossal reflex in rats. J. Physiol. Pharmacol. 2007, 58, 479-486.

47. Kong, Q.; Yu, L.C. Antinociceptive effects induced by intra-periaqueductal grey injection of the galanin receptor 1 agonist M617 in rats with morphine tolerance. Neurosci. Lett. 2013, 550, 125-128. [CrossRef]

48. Zhang, X.Y.; Zhang, Y.M.; Zhang, M.L.; Yu, L.C. Involvement of galanin receptor 2 and CaMKII in galanin-induced antinociception in periaqueductal grey of rats. Neurosci. Lett. 2015, 604, 124-127. [CrossRef]

49. Sun, Y.G.; Yu, L.C. Interactions of galanin and opioids in nociceptive modulation in the arcuate nucleus of hypothalamus in rats Regul. Pept. 2005, 124, 37-43. [CrossRef]

50. Sun, Y.G.; Gu, X.L.; Yu, L.C. The neural pathway of galanin in the hypothalamic arcuate nucleus of rats: Activation of betaendorphinergic neurons projecting to periaqueductal gray matter. J. Neurosci. Res. 2007, 85, 2400-2406. [CrossRef]

51. Zhang, M.D.; Barde, S.; Yang, T.; Lei, B.; Eriksson, L.I.; Mathew, J.P.; Andreska, T.; Akassoglou, K.; Harkany, T.; Hökfelt, T.G.M.; et al Orthopedic surgery modulates neuropeptides and BDNF expression at the spinal and hippocampal levels. Proc. Natl. Acad. Sci. USA 2016, 113, E6686-E6695. [CrossRef] [PubMed]

52. Holmes, F.E.; Kerr, N.; Chen, Y.J.; Vanderplank, P.; McArdle, C.A.; Wynick, D. Targeted disruption of the orphan receptor Gpr151 does not alter pain-related behaviour despite a strong induction in dorsal root ganglion expression in a model of neuropathic pain. Mol. Cell. Neurosci. 2017, 78, 35-40. [CrossRef] [PubMed]

53. Rydh-Rinder, M.; Holmberg, K.; Elfvin, L.G.; Wiesenfeld-Hallin, Z.; Hökfelt, T. Effects of peripheral axotomy on neuropeptides and nitric oxide synthase in dorsal root ganglia and spinal cord of the guinea pig: An immunohistochemical study. Brain Res. 1996, 707, 180-188. [CrossRef]

54. Ji, R.R.; Zhang, Q.; Pettersson, R.F.; Hökfelt, T. aFGF, bFGF and NGF differentially regulate neuropeptide expression in dorsal root ganglia after axotomy and induce autotomy. Regul. Pept. 1996, 66, 179-189. [CrossRef]

55. Corness, J.; Shi, T.J.; Xu, Z.Q.; Brulet, P.; Hökfelt, T. Influence of leukemia inhibitory factor on galanin/GMAP and neuropeptide Y expression in mouse primary sensory neurons after axotomy. Exp. Brain Res. 1996, 112, 79-88. [CrossRef]

56. Ma, W.; Bisby, M.A. Differential expression of galanin immunoreactivities in the primary sensory neurons following partial and complete sciatic nerve injuries. Neuroscience 1997, 79, 1183-1195. [CrossRef]

57. Shi, T.J.; Zhang, X.; Berge, O.G.; Erickson, J.C.; Palmiter, R.D.; Hökfelt, T. Effect of peripheral axotomy on dorsal root ganglion neuron phenotype and autotomy behaviour in neuropeptide Y-deficient mice. Regul. Pept. 1998, 75-76, 161-173. [CrossRef]

58. Fukuoka, T.; Tokunaga, A.; Kondo, E.; Miki, K.; Tachibana, T.; Noguchi, K. Change in mRNAs for neuropeptides and the GABA(A) receptor in dorsal root ganglion neurons in a rat experimental neuropathic pain model. Pain 1998, 78, 13-26. [CrossRef]

59. Macdonald, R.; Bingham, S.; Bond, B.C.; Parsons, A.A.; Philpott, K.L. Determination of changes in mRNA expression in a rat model of neuropathic pain by Taqman ${ }^{\mathrm{TM}}$ quantitative RT-PCR. Mol. Brain Res. 2001, 90, 48-56. [CrossRef]

60. Wang, L.H.; Lu, Y.J.; Bao, L.; Zhang, X. Peripheral nerve injury induces reorganization of galanin-containing afferents in the superficial dorsal horn of monkey spinal cord. Eur. J. Neurosci. 2007, 25, 1087-1096. [CrossRef]

61. Nahin, R.L.; Ren, K.; De León, M.; Ruda, M. Primary sensory neurons exhibit altered gene expression in a rat model of neuropathic pain. Pain 1994, 58, 95-108. [CrossRef]

62. Wilson-Gerwing, T.D.; Verge, V.M.K. Neurotrophin-3 attenuates galanin expression in the chronic constriction injury model of neuropathic pain. Neuroscience 2006, 141, 2075-2085. [CrossRef] [PubMed]

63. Reinhold, A.K.; Batti, L.; Bilbao, D.; Buness, A.; Rittner, H.L.; Heppenstall, P.A. Differential transcriptional profiling of damaged and intact adjacent dorsal root ganglia neurons in neuropathic pain differential transcriptional profiling of damaged and intact adjacent dorsal root ganglia neurons in neuropathic pain. PLoS ONE 2015, 10, e0123342. [CrossRef] [PubMed]

64. Barajon, I.; Bersani, M.; Quartu, M.; Del Fiacco, M.; Cavaletti, G.; Holst, J.J.; Tredici, G. Neuropeptides and morphological changes in cisplatin-induced dorsal root ganglion neuronopathy. Exp. Neurol. 1996, 138, 93-104. [CrossRef] [PubMed] 
65. Coronel, M.F.; Brumovsky, P.R.; Hökfelt, T.; Villar, M.J. Differential galanin upregulation in dorsal root ganglia and spinal cord after graded single ligature nerve constriction of the rat sciatic nerve. J. Chem. Neuroanat. 2008, 35, 94-100. [CrossRef]

66. Coronel, M.F.; Musolino, P.L.; Brumovsky, P.R.; Hökfelt, T.; Villar, M.J. Bone marrow stromal cells attenuate injury-induced changes in galanin, NPY and NPY Y1-receptor expression after a sciatic nerve constriction. Neuropeptides 2009, 43, 125-132. [CrossRef]

67. Zhang, Y.P.; Fu, E.S.; Sagen, J.; Levitt, R.C.; Candiotti, K.A.; Bethea, J.R.; Brambilla, R. Glial NF-kappa B inhibition alters neuropeptide expression after sciatic nerve injury in mice. Brain Res. 2011, 1385, 38-46. [CrossRef]

68. Long, A.; Bongenhielm, U.; Boissonade, F.M.; Fried, K.; Robinson, P.P. Neuropeptide immunereactivity in ligature-induced neuromas of the inferior alveolar nerve in the ferret. Brain Res. 1998, 791, 263-270. [CrossRef]

69. Bird, E.V.; Long, A.; Boissonade, F.M.; Fried, K.; Robinson, P.P. Neuropeptide expression following constriction or section of the inferior alveolar nerve in the ferret. J. Peripher. Nerv. Syst. 2002, 7, 168-180. [CrossRef]

70. Liu, F.; Yajima, T.; Wang, M.; Shen, J.F.; Ichikawa, H.; Sato, T. Effects of trigeminal nerve injury on the expression of galanin and its receptors in the rat trigeminal ganglion. Neuropeptides 2020, 84, 102098. [CrossRef]

71. Sten Shi, T.J.; Cui, J.G.; Meyerson, B.A.; Linderoth, B.; Hökfelt, T. Regulation of galanin and neuropeptide Y in dorsal root ganglia and dorsal horn in rat mononeuropathic models: Possible relation to tactile hypersensitivity. Neuroscience 1999, 93, 741-757. [CrossRef]

72. Wang, R.; Guo, W.; Ossipov, M.H.; Vanderah, T.W.; Porreca, F.; Lai, J. Glial cell line-derived neurotrophic factor normalizes neurochemical changes in injured dorsal root ganglion neurons and prevents the expression of experimental neuropathic pain. Neuroscience 2003, 121, 815-824. [CrossRef]

73. Peters, C.M.; Ghilardi, J.R.; Keyser, C.P.; Kubota, K.; Lindsay, T.H.; Luger, N.M.; Mach, D.B.; Schwei, M.J.; Sevcik, M.A.; Mantyh, P.W. Tumor-induced injury of primary afferent sensory nerve fibers in bone cancer pain. Exp. Neurol. 2005, 193, 85-100. [CrossRef]

74. Garry, E.M.; Delaney, A.; Anderson, H.A.; Sirinathsinghji, E.C.; Clapp, R.H.; Martin, W.J.; Kinchington, P.R.; Krah, D.L.; Abbadie, C.; Fleetwood-Walker, S.M. Varicella zoster virus induces neuropathic changes in rat dorsal root ganglia and behavioral reflex sensitisation that is attenuated by gabapentin or sodium channel blocking drugs. Pain 2005, 118, 97-111. [CrossRef]

75. Hulse, R.; Wynick, D.; Donaldson, L.F. Characterization of a novel neuropathic pain model in mice. Neuroreport 2008, 19, 825-829. [CrossRef]

76. Xu, X.F.; Zhang, D.D.; Liao, J.C.; Xiao, L.; Wang, Q.; Qiu, W. Galanin and its receptor system promote the repair of injured sciatic nerves in diabetic rats. Neural Regen. Res. 2016, 11, 1517-1526. [CrossRef]

77. Boateng, E.K.; Novejarque, A.; Pheby, T.; Rice, A.S.C.; Huang, W. Heterogeneous responses of dorsal root ganglion neurons in neuropathies induced by peripheral nerve trauma and the antiretroviral drug stavudine. Eur. J. Pain 2015, 19, 236-245. [CrossRef] [PubMed]

78. Chen, S.H.; Lue, J.H.; Hsiao, Y.J.; Lai, S.M.; Wang, H.Y.; Lin, C.T.; Chen, Y.C.; Tsai, Y.J. Elevated galanin receptor type 2 primarily contributes to mechanical hypersensitivity after median nerve injury. PLoS ONE 2018, 13, e0199512. [CrossRef]

79. Calzà, L.; Pozza, M.; Arletti, R.; Manzini, E.; Hökfelt, T. Long-lasting regulation of galanin, opioid, and other peptides in dorsal root ganglia and spinal cord during experimental polyarthritis. Exp. Neurol. 2000, 164, 333-343. [CrossRef]

80. Su, J.; Gao, T.; Shi, T.; Xiang, Q.; Xu, X.; Wiesenfeld-Hallin, Z.; Hökfelt, T.; Svensson, C.I. Phenotypic changes in dorsal root ganglion and spinal cord in the collagen antibody-induced arthritis mouse model. J. Comp. Neurol. 2015, 523, 1505-1528 [CrossRef]

81. Hope, P.J.; Lang, C.W.; Grubb, B.D.; Duggan, A.W. Release of immunoreactive galanin in the spinal cord of rats with ankle inflammation: Studies with antibody microprobes. Neuroscience 1994, 60, 801-807. [CrossRef]

82. Liu, H.X.; Brumovsky, P.; Schmidt, R.; Brown, W.; Payza, K.; Hodzic, L.; Pou, C.; Godbout, C.; Hökfelt, T. Receptor subtype-specific pronociceptive and analgesic actions of galanin in the spinal cord: Selective actions via Galr1 and Galr2 receptors. Proc. Natl. Acad. Sci. USA 2001, 98, 9960-9964. [CrossRef] [PubMed]

83. Carlton, S.M.; Coggeshall, R.E. Stereological analysis of galanin and CGRP synapses in the dorsal horn of neuropathic primates Brain Res. 1996, 711, 16-25. [CrossRef]

84. Colvin, L.A.; Duggan, A.W. Primary afferent-evoked release of immunoreactive galanin in the spinal cord of the neuropathic rat. Br. J. Anaesth. 1998, 81, 436-443. [CrossRef] [PubMed]

85. Ma, W.; Bisby, M.A. Ultrastructural localization of increased neuropeptide immunoreactivity in the axons and cells of the gracile nucleus following chronic constriction injury of the sciatic nerve. Neuroscience 1999, 93, 335-348. [CrossRef]

86. Coronel, M.F.; Villar, M.J.; Brumovsky, P.R.; González, S.L. Spinal neuropeptide expression and neuropathic behavior in the acute and chronic phases after spinal cord injury: Effects of progesterone administration. Peptides 2017, 88, 189-195. [CrossRef]

87. Munglani, R.; Harrison, S.M.; Smith, G.D.; Bountra, C.; Birch, P.J.; Elliot, P.J.; Hunt, S.P. Neuropeptide changes persist in spinal cord despite resolving hyperalgesia in a rat model of mononeuropathy. Brain Res. 1996, 743, 102-108. [CrossRef]

88. Calzà, L.; Pozza, M.; Zanni, M.; Manzini, C.U.; Manzini, E.; Hökfelt, T. Peptide plasticity in primary sensory neurons and spinal cord during adjuvant-induced arthritis in the rat: An immunocytochemical and in situ hybridization study. Neuroscience 1997, 82, 575-589. [CrossRef]

89. Imbe, H.; Abe, T.; Okamoto, K.; Sato, M.; Ito, H.; Kumabe, S.; Senba, E. Increase of galanin-like immunoreactivity in rat hypothalamic arcuate neurons after peripheral nerve injury. Neurosci. Lett. 2004, 368, 102-106. [CrossRef] 
90. Nishii, H.; Nomura, M.; Aono, H.; Fujimoto, N.; Matsumoto, T. Up-regulation of galanin and corticotropin-releasing hormone mRNAs in the key hypothalamic and amygdaloid nuclei in a mouse model of visceral pain. Regul. Pept. 2007, 141, 105-112. [CrossRef]

91. Amorim, D.; David-Pereira, A.; Marques, P.; Puga, S.; Rebelo, P.; Costa, P.; Pertovaara, A.; Almeida, A.; Pinto-Ribeiro, F. A role of supraspinal galanin in behavioural hyperalgesia in the rat. PLOS ONE 2014, 9, e113077. [CrossRef] [PubMed]

92. Zhang, Y.; Gao, Y.; Li, C.Y.; Dong, W.; Li, M.N.; Liu, Y.N.; Dong, Y.; Xu, S.L. Galanin plays a role in antinociception via binding to galanin receptors in the nucleus accumbens of rats with neuropathic pain. Neurosci. Lett. 2019, 706, 93-98. [CrossRef] [PubMed]

93. Fernandez-Zafra, T.; Gao, T.; Jurczak, A.; Sandor, K.; Hore, Z.; Agalave, N.M.; Su, J.; Estelius, J.; Lampa, J.; Hokfelt, T.; et al Exploring the transcriptome of resident spinal microglia after collagen antibody-induced arthritis. Pain 2019, 160, $224-236$. [CrossRef]

94. Pope, R.J.P.; Holmes, F.E.; Kerr, N.C.; Wynick, D. Characterisation of the nociceptive phenotype of suppressible galanin overexpressing transgenic mice. Mol. Pain 2010, 6, 67. [CrossRef] [PubMed]

95. Hygge-Blakeman, K.; Brumovsky, P.; Hao, J.X.; Xu, X.J.; Hökfelt, T.; Crawley, J.N.; Wiesenfeld-Hallin, Z. Galanin over-expression decreases the development of neuropathic pain-like behaviors in mice after partial sciatic nerve injury. Brain Res. 2004, 1025, 152-158. [CrossRef]

96. Holmberg, K.; Kuteeva, E.; Brumovsky, P.; Kahl, U.; Karlström, H.; Lucas, G.A.; Rodriguez, J.; Westerblad, H.; Hilke, S.; Theodorsson, E.; et al. Generation and phenotypic characterization of a galanin over-expressing mouse. Neuroscience 2005, 133, 59-77. [CrossRef] [PubMed]

97. Wiesenfeld-Hallin, Z.; Xu, X.J.; Villar, M.J.; Hökfelt, T. The effect of intrathecal galanin on the flexor reflex in rat: Increased depression after sciatic nerve section. Neurosci. Lett. 1989, 105, 149-154. [CrossRef]

98. Satoh, M.; Kuraishi, Y.; Kawamura, M. Effects of intrathecal antibodies to substance P, calcitonin gene-related peptide and galanin on repeated cold stress-induced hyperalgesia: Comparison with carrageenan-induced hyperalgesia. Pain 1992, 49, 273-278. [CrossRef]

99. Wiesenfeld-Hallin, Z.; Xu, X.J.; Langel, U.; Bedecs, K.; Hokfelt, T.; Bartfai, T. Galanin-mediated control of pain: Enhanced role after nerve injury. Proc. Natl. Acad. Sci. USA 1992, 89, 3334-3337. [CrossRef]

100. Verge, V.M.K.; Xu, X.J.; Langel, Ü.; Hökfelt, T.; Wiesenfeld-Hallin, Z.; Bartfai, T. Evidence for endogenous inhibition of autotomy by galanin in the rat after sciatic nerve section: Demonstrated by chronic intrathecal infusion of a high affinity galanin receptor antagonist. Neurosci. Lett. 1993, 149, 193-197. [CrossRef]

101. Hulse, R.P.; Donaldson, L.F.; Wynick, D. Differential roles of galanin on mechanical and cooling responses at the primary afferent nociceptor. Mol. Pain 2012, 8, 1-11. [CrossRef] [PubMed]

102. Jimenez-Andrade, J.M.; Zhou, S.; Du, J.; Yamani, A.; Grady, J.J.; Castañeda-Hernandez, G.; Carlton, S.M. Pro-nociceptive role of peripheral galanin in inflammatory pain. Pain 2004, 110, 10-21. [CrossRef] [PubMed]

103. Jimenez-Andrade, J.M.; Zhou, S.; Yamani, A.; Valencia De Ita, S.; Castañeda-Hernandez, G.; Carlton, S.M. Mechanism by which peripheral galanin increases acute inflammatory pain. Brain Res. 2005, 1056, 113-117. [CrossRef]

104. Jimenez-Andrade, J.M.; Lundström, L.; Sollenberg, U.E.; Langel, Ü.; Castañeda-Hernandez, G.; Carlton, S.M. Activation of peripheral galanin receptors: Differential effects on nociception. Pharmacol. Biochem. Behav. 2006, 85, 273-280. [CrossRef]

105. Lundeberg, T.; Meister, B.; Björkstrand, E.; Uvnäs-Moberg, K. Oxytocin modulates the effects of galanin in carrageenan-induced hyperalgesia in rats. Brain Res. 1993, 608, 181-185. [CrossRef]

106. Luo, L.; Wiesenfeld-Hallin, Z. The effects of pretreatment with tachykinin antagonists and galanin on the development of spinal cord hyperexcitability following sciatic nerve section in the rat. Neuropeptides 1995, 28, 161-166. [CrossRef]

107. Kerr, B.J.; Cafferty, W.B.J.; Gupta, Y.K.; Bacon, A.; Wynick, D.; McMahon, S.B.; Thompson, S.W.N. Galanin knockout mice reveal nociceptive deficits following peripheral nerve injury. Eur. J. Neurosci. 2000, 12, 793-802. [CrossRef] [PubMed]

108. Hao, J.X. Intrathecal galanin alleviates allodynia-like behaviour in rats after partial peripheral nerve injury. Eur. J. Neurosci. 1999, 11, 427-432. [CrossRef] [PubMed]

109. Liu, H.X.; Hökfelt, T. Effect of intrathecal galanin and its putative antagonist M35 on pain behavior in a neuropathic pain model. Brain Res. 2000, 886, 67-72. [CrossRef]

110. Xu, S.L.; Zhang, Y.P.; Lundeberg, T.; Yu, L.C. Effects of galanin on wide-dynamic range neuron activity in the spinal dorsal horn of rats with sciatic nerve ligation. Regul. Pept. 2000, 95, 19-23. [CrossRef]

111. Hu, P.; McLachlan, E.M. Long-term changes in the distribution of galanin in dorsal root ganglia after sciatic or spinal nerve transection in rats. Neuroscience 2001, 103, 1059-1071. [CrossRef]

112. Flatters, S.J.L.; Fox, A.J.; Dickenson, A.H. Nerve injury induces plasticity that results in spinal inhibitory effects of galanin. Pain 2002, 98, 249-258. [CrossRef]

113. Flatters, S.J.L.; Fox, A.J.; Dickenson, A.H. In vivo and in vitro effects of peripheral galanin on nociceptive transmission in naive and neuropathic states. Neuroscience 2003, 116, 1005-1012. [CrossRef]

114. Xiong, W.; Gao, L.; Sapra, A.; Yu, L.C. Antinociceptive role of galanin in the spinal cord of rats with inflammation, an involvement of opioid systems. Regul. Pept. 2005, 132, 85-90. [CrossRef]

115. Jung, S.J.; Chang, J.W.; Won, R.; Cha, M.H.; Nam, T.S.; Lee, H.J.; Lee, B.H. Modulation of neuropathic pain by galanin and neuropeptide y at the level of the medulla in rats. Int. J. Neurosci. 2009, 119, 1941-1955. [CrossRef] [PubMed] 
116. Xu, X.; Liu, Z.; Liu, H.; Yang, X.; Li, Z. The effects of galanin on neuropathic pain in streptozotocin-induced diabetic rats. Eur. J. Pharmacol. 2012, 680, 28-33. [CrossRef] [PubMed]

117. Hulse, R.P.; Wynick, D.; Donaldson, L.F. Activation of the galanin receptor 2 in the periphery reverses nerve injury-induced allodynia. Mol. Pain 2011, 7, 26. [CrossRef]

118. Sten Shi, T.J.; Zhang, X.; Holmberg, K.; Xu, Z.Q.D.; Hökfelt, T. Expression and regulation of galanin-R2 receptors in rat primary sensory neurons: Effect of axotomy and inflammation. Neurosci. Lett. 1997, 237, 57-60. [CrossRef]

119. Botz, B.; Kemény, Á.; Brunner, S.M.; Locker, F.; Csepregi, J.; Mócsai, A.; Pintér, E.; McDougall, J.J.; Kofler, B.; Helyes, Z. Lack of Galanin 3 Receptor Aggravates Murine Autoimmune Arthritis. J. Mol. Neurosci. 2016, 59, 260-269. [CrossRef]

120. Wu, S.; Marie Lutz, B.; Miao, X.; Liang, L.; Mo, K.; Chang, Y.J.; Du, P.; Soteropoulos, P.; Tian, B.; Kaufman, A.G.; et al. Dorsal root ganglion transcriptome analysis following peripheral nerve injury in mice. Mol. Pain 2016, 12, 1744806916629048. [CrossRef]

121. Blakeman, K.H.; Hao, J.X.; Xu, X.J.; Jacoby, A.S.; Shine, J.; Crawley, J.N.; Iismaa, T.; Wiesenfeld-Hallin, Z. Hyperalgesia and increased neuropathic pain-like response in mice lacking galanin receptor 1 receptors. Neuroscience 2003, 117, 221-227. [CrossRef]

122. Malkmus, S.; Lu, X.; Bartfai, T.; Yaksh, T.L.; Hua, X.Y. Increased hyperalgesia after tissue injury and faster recovery of allodynia after nerve injury in the GalR1 knockout mice. Neuropeptides 2005, 39, 217-221. [CrossRef] [PubMed]

123. Zhang, Y.; Gao, Y.; Li, C.Y.; Dong, W.; Dong, Y.; Li, M.N.; Liu, Y.N.; Xu, S.L. Galanin receptor 1 plays an antinociceptive effect via inhibiting PKA activation in the nucleus accumbens of rats with neuropathic pain. Physiol. Res. 2019, 68, 511-518. [CrossRef]

124. Lyu, C.; Xia, S.; Lyu, G.W.; Dun, X.P.; Zheng, K.; Su, J.; Barde, S.; Xu, Z.Q.D.; Hökfelt, T.; Shi, T.J.S. A preliminary study on DRGs and spinal cord of a galanin receptor 2-EGFP transgenic mouse. Neuropeptides 2020, 79, 102000. [CrossRef]

125. Shi, T.J.S.; Hua, X.Y.; Lu, X.; Malkmus, S.; Kinney, J.; Holmberg, K.; Wirz, S.; Ceccatelli, S.; Yaksh, T.; Bartfai, T.; et al. Sensory neuronal phenotype in galanin receptor 2 knockout mice: Focus on dorsal root ganglion neurone development and pain behaviour. Eur. J. Neurosci. 2006, 23, 627-636. [CrossRef]

126. Brumovsky, P.; Mennicken, F.; O’Donnell, D.; Hökfelt, T. Differential distribution and regulation of galanin receptors- 1 and -2 in the rat lumbar spinal cord. Brain Res. 2006, 1085, 111-120. [CrossRef]

127. Metcalf, C.S.; Klein, B.D.; McDougle, D.R.; Zhang, L.; Smith, M.D.; Bulaj, G.; White, H.S. Analgesic properties of a peripherally acting and GalR2 receptor-Preferring galanin analog in inflammatory, neuropathic, and acute pain models. J. Pharmacol. Exp. Ther. 2015, 352, 185-193. [CrossRef] [PubMed]

128. Duan, H.; Zhang, Y.; Zhang, X.M.; Xu, H.H.; Shu, J.; Xu, S.L. Antinociceptive roles of galanin receptor 1 in nucleus accumbens of rats in a model of neuropathic pain. J. Neurosci. Res. 2015, 93, 1542-1551. [CrossRef] [PubMed]

129. Dong, Y.; Li, C.Y.; Zhang, X.M.; Liu, Y.N.; Yang, S.; Li, M.N.; Xu, S.L. The activation of galanin receptor 2 plays an antinociceptive effect in nucleus accumbens of rats with neuropathic pain. J. Physiol. Sci. 2021, 71, 6. [CrossRef]

130. Li, M.; Zhang, X.; Li, C.; Liu, Y.; Yang, S.; Xu, S. Galanin Receptor 2 Is Involved in Galanin-Induced Analgesic Effect by Activating PKC and CaMKII in the Nucleus Accumbens of Inflammatory Pain Rats. Front. Neurosci. 2021, 14, 1466. [CrossRef]

131. Li, S.Y.; Huo, M.L.; Wu, X.Y.; Huang, Y.Q.; Wang, L.; Zhang, X.; Jiang, Y.M.; Zhang, M.L.; Wang, L.L.; Yu, L.C. Involvement of galanin and galanin receptor 1 in nociceptive modulation in the central nucleus of amygdala in normal and neuropathic rats. Sci. Rep. 2017, 7, 15317. [CrossRef] [PubMed]

132. Sun, Y.G.; Li, J.; Yang, B.N.; Yu, L.C. Antinociceptive effects of galanin in the rat tuberomammillary nucleus and the plasticity of galanin receptor 1 during hyperalgesia. J. Neurosci. Res. 2004, 77, 718-722. [CrossRef]

133. Zhang, M.L.; Wang, H.B.; Fu, F.H.; Yu, L.C. Involvement of galanin and galanin receptor 2 in nociceptive modulation in anterior cingulate cortex of normal rats and rats with mononeuropathy. Sci. Rep. 2017, 7, 45930. [CrossRef] [PubMed]

134. Wang, D.; Lundeberg, T.; Yu, L.C. Antinociceptive role of galanin in periaqueductal grey of rats with experimentally induced mononeuropathy. Neuroscience 2000, 96, 767-771. [CrossRef]

135. Sun, Y.G.; Gu, X.L.; Lundeberg, T.; Yu, L.C. An antinociceptive role of galanin in the arcuate nucleus of hypothalamus in intact rats and rats with inflammation. Pain 2003, 106, 143-150. [CrossRef]

136. Gu, X.L.; Sun, Y.G.; Yu, L.C. Involvement of galanin in nociceptive regulation in the arcuate nucleus of hypothalamus in rats with mononeuropathy. Behav. Brain Res. 2007, 179, 331-335. [CrossRef]

137. Yang, Y.; Zhang, Y.; Li, X.H.; Li, Y.; Qian, R.; Li, J.; Xu, S.L. Involvements of galanin and its receptors in antinociception in nucleus accumbens of rats with inflammatory pain. Neurosci. Res. 2015, 97, 20-25. [CrossRef]

138. Zhang, M.L.; Fu, F.H.; Yu, L.C. Antinociception induced by galanin in anterior cingulate cortex in rats with acute inflammation. Neurosci. Lett. 2017, 638, 156-161. [CrossRef]

139. An, K.; Xu, Y.; Yang, H.; Shu, H.H.; Xiang, H.B.; Tian, Y.K. Subarachnoid transplantation of immortalized galanin-over-expressing astrocytes attenuates chronic neuropathic pain. Eur. J. Pain 2010, 14, 595-601. [CrossRef]

140. Zhang, Y.P.; Lundeberg, T.; Yu, L.C. Interactions of galanin and morphine in the spinal antinociception in rats with mononeuropathy. Brain Res. 2000, 852, 485-487. [CrossRef]

141. Zhang, Y.P.; Yu, L.C.; Lundeberg, T. An interaction of opioids and galanin in dorsal horn of the spinal cord in mononeuropathic rats. Regul. Pept. 2000, 86, 89-94. [CrossRef]

142. Kerr, B.J.; Gupta, Y.; Pope, R.; Thompson, S.W.N.; Wynick, D.; McMahon, S.B. Endogenous galanin potentiates spinal nociceptive processing following inflammation. Pain 2001, 93, 267-277. [CrossRef] 
143. Ji, R.R.; Zhang, Q.; Bedecs, K.; Arvidsson, J.; Zhang, X.; Xu, X.J.; Wiesenfeld- Hallin, Z.; Bartfai, T.; Hokfelt, T. Galanin antisense oligonucleotides reduce galanin levels in dorsal root ganglia and induce autotomy in rats after axotomy. Proc. Natl. Acad. Sci. USA 1994, 91, 12540-12543. [CrossRef] [PubMed]

144. Heppelmann, B.; Just, S.; Pawlak, M. Galanin influences the mechanosensitivity of sensory endings in the rat knee joint. Eur. J. Neurosci. 2000, 12, 1567-1572. [CrossRef] [PubMed]

145. Honore, P.; Rogers, S.D.; Schwei, M.J.; Salak-Johnson, J.L.; Luger, N.M.; Sabino, M.C.; Clohisy, D.R.; Mantyh, P.W. Murine models of inflammatory, neuropathic and cancer pain each generates a unique set of neurochemical changes in the spinal cord and sensory neurons. Neuroscience 2000, 98, 585-598. [CrossRef]

146. Ma, W.; Bisby, M.A. Increase of galanin mRNA in lumbar dorsal root ganglion neurons of adult rats after partial sciatic nerve ligation. Neurosci. Lett. 1999, 262, 195-198. [CrossRef]

147. Hofmann, H.A.; De Vry, J.; Siegling, A.; Spreyer, P.; Denzer, D. Pharmacological sensitivity and gene expression analysis of the tibial nerve injury model of neuropathic pain. Eur. J. Pharmacol. 2003, 470, 17-25. [CrossRef]

148. Wallace, V.C.J.; Blackbeard, J.; Pheby, T.; Segerdahl, A.R.; Davies, M.; Hasnie, F.; Hall, S.; McMahon, S.B.; Rice, A.S.C. Pharmacological, behavioural and mechanistic analysis of HIV-1 gp120 induced painful neuropathy. Pain 2007, 133, 47-63. [CrossRef]

149. Bao, L.; Wang, H.F.; Cai, H.J.; Tong, Y.G.; Jin, S.X.; Lu, Y.J.; Grant, G.; Hökfelt, T.; Zhang, X. Peripheral axotomy induces only very limited sprouting of coarse myelinated afferents into inner lamina II of rat spinal cord. Eur. J. Neurosci. 2002, 16, 175-185. [CrossRef]

150. Yu, L.C.; Lundeberg, S.; An, H.; Wang, F.X.; Lundeberg, T. Effects of intrathecal galanin on nociceptive responses in rats with mononeuropathy. Life Sci. 1999, 64, 1145-1153. [CrossRef]

151. Sundström, E.; Melander, T. Effects of galanin on 5-HT neurons in the rat CNS. Eur. J. Pharmacol. 1988, 146, 327-329. [CrossRef]

152. Webling, K.E.B.; Runesson, J.; Bartfai, T.; Langel, Ü. Galanin receptors and ligands. Front. Endocrinol. 2012, 3. [CrossRef] [PubMed]

153. Lang, R.; Gundlach, A.L.; Kofler, B. The galanin peptide family: Receptor pharmacology, pleiotropic biological actions, and implications in health and disease. Pharmacol. Ther. 2007, 115, 177-207. [CrossRef]

154. Gustafson, E.L.; Smith, K.E.; Durkin, M.M.; Gerald, C.; Branchek, T.A. Distribution of a rat galanin receptor mRNA in rat brain Neuroreport 1996, 7, 953-957. [CrossRef] [PubMed]

155. Lundström, L.; Sollenberg, U.; Brewer, A.; Kouya, P.F.; Zheng, K.; Xu, X.J.; Sheng, X.; Robinson, J.K.; Wiesenfeld-Hallin, Z.; Xu, Z.Q.; et al. A galanin receptor subtype 1 specific agonist. Int. J. Pept. Res. Ther. 2005, 11, 17-27. [CrossRef]

156. O'Donnell, D.; Ahmad, S.; Wahlestedt, C.; Walker, P. Expression of the novel galanin receptor subtype GALR2 in the adult rat CNS: Distinct distribution from GALR. J. Comp. Neurol. 1999, 409, 469-481. [CrossRef]

157. Borroto-Escuela, D.O.; Pita-Rodriguez, M.; Fores-Pons, R.; Barbancho, M.A.; Fuxe, K.; Narváez, M. Galanin and neuropeptide Y interactions elicit antidepressant activity linked to neuronal precursor cells of the dentate gyrus in the ventral hippocampus. J. Cell. Physiol. 2021, 236, 3565-3578. [CrossRef]

158. Narváez, M.; Millón, C.; Borroto-Escuela, D.; Flores-Burgess, A.; Santín, L.; Parrado, C.; Gago, B.; Puigcerver, A.; Fuxe, K.; Narváez, J.A.; et al. Galanin receptor 2-neuropeptide Y Y1 receptor interactions in the amygdala lead to increased anxiolytic actions. Brain Struct. Funct. 2015, 220, 2289-2301. [CrossRef]

159. Mennicken, F.; Hoffert, C.; Pelletier, M.; Ahmad, S.; O'Donnell, D. Restricted distribution of galanin receptor 3 (GalR3) mRNA in the adult rat central nervous system. J. Chem. Neuroanat. 2002, 24, 257-268. [CrossRef]

160. Zhang, X.; Nicholas, A.P.; Hökfelt, T. Ultrastructural studies on peptides in the dorsal horn of the rat spinal cord-II. Co-existence of galanin with other peptides in local neurons. Neuroscience 1995, 64, 875-891. [CrossRef]

161. Stevens, C.W.; Kajander, K.C.; Bennett, G.J.; Seybold, V.S. Bilateral and differential changes in spinal mu, delta and kappa opioid binding in rats with a painful, unilateral neuropathy. Pain 1991, 46, 315-326. [CrossRef] 